EDITORIAL

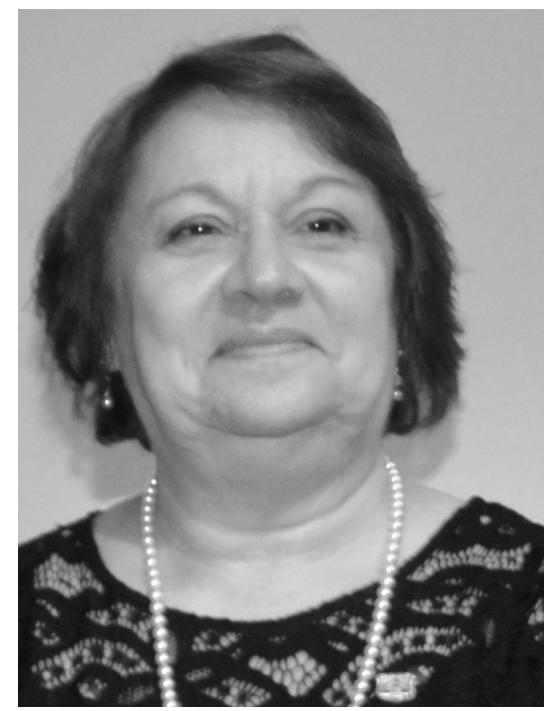

* Part of the speech given at inauguration, São Paulo, SP, Brazil, 2015.

${ }^{1}$ Universidade de São Paulo, Escola de Enfermagem, Departamento de Enfermagem em Saúde Coletiva, São Paulo, SP, Brazil.

E-mail: macampos@usp.br

${ }^{2}$ Director, Escola de Enfermagem, Universidade de São Paulo. President of the Editorial Board of the Revista da Escola de Enfermagem da USP.
DOI: http://dx.doi.org/10.1590/S0080-623420160000100001

\section{UNIVERSITY OF SÃO PAULO SCHOOL OF \\ NURSING: a world-class school*}

Maria Amélia de Campos Oliveira ${ }^{1,2}$

How to cite this article:

Oliveira MAC. University of São Paulo School of Nursing: a world-class school [editorial]. Rev Esc Enferm USP. 2016;50(1):10-1. DOI: http://dx.doi.org/10.1590/S0080-623420160000100001

The University of São Paulo (USP) is the most important university in Brazil, Latin America and the Caribbean. One of Brazil's scientific, cultural and social heritages, the University celebrated its 80th anniversary in $2014^{(1)}$. Therefore, it is expected that its faculties and departments be both a national and international reference in the realms of education, research, and university continuing education.

The University of São Paulo School of Nursing (EEUSP), as per its acronym in Portuguese) certainly is. In her recent visit to the school, Dr. Judith Shamian, chairman of the International Nursing Council and member of the Institutional Assessment Committee, classified EEUSP as a world-class school. Nonetheless, it is also necessary for this school to be an ethical and political reference in the forefront of the discussions about the direction taken by the fields of education and health in Brazil, especially at this time of crisis when one of the most important conquests by Brazilian social movements, the Unified Health System (SUS, as per its acronym in Portuguese) ${ }^{(2)}$, is threatened. Additionally, because it is part of a publicly funded university, EEUSP must take regular accountability before the society that keeps it, in a totally transparent and unbiased way.

Even though the University of São Paulo is a research-focused university, its social recognition comes mainly from the education it provides, particularly at the undergraduate level. Its highly competitive entrance examination is the expression that Brazilians want to have their children at USP. Therefore, to distinguish itself for its excellence in both undergraduate and graduate education is another commitment by USP's School of Nursing.

The school's scientific production is a contribution to the Brazilian society, to nursing, and to the health care area. Between 2010 and 2014, EEUSP's professors published more than 250 articles a year both in national and international journals, totaling 1,370 articles in five years - an evidence of its significant participation in the Brazilian nursing scientific production.

EEUSP is a small school at USP. With a reduced number of professors and administrative and technical staff, it plays an active role in the construction of the university. Engaged in USP's global movement, the School is actively involved in most of the initiatives proposed by the University and stands out for its engagement in teaching, research, and continuing education activities. It is necessary to take advantage of this participative, creative potential to create solutions that will enhance the value of people and the work they do.

Teaching, research, and continuing education - the tripod on which the university's work rests and the ultimate purpose of public universities - are the focus of this administration.

EEUSP's undergraduate program is lined up with contemporary trends in the field of teaching and learning. The new political-educational projects for the 
bachelor's and licentiate programs, established in 2010, are this school's answer to the need for training workers for (SUS) ${ }^{(2)}$.

To strengthen the professional practice is an important part of this academic group's commitment to the Brazilian population's health. Five years after the implementation of the new curriculums, it is time to perform an in-depth assessment of our advances and limitations that must be overcome.

EEUSP's graduate program is one of the oldest in this country and is fully consolidated. Of the five existing programs in this school, two have already reached levels of excellence, with grades 6 and 7 in the assessment by the Coordination for the Improvement of Higher Education Personnel (Capes, as per its acronym in Portuguese). The others were considered "Very Good," which corresponds to grade 5. The professional master's degree, our latest initiative, received grade 4 as a newly created program and will harvest its first fruits very soon.

We must maintain the quality of these programs and go forward toward new levels of national and international exchange as a contribution in training academic leaders for teaching, research, and assistance in nursing and health.

Our research program has also reached significant results with an increase in the number of students who have been granted scholarships for the Productivity in Research program of Brazil's National Council for Scientific and Technological Development (CNPq, as per its acronym in Portuguese), in addition to projects sponsored by promotion agencies - particularly the São Paulo Research Foundation - and post-doctoral grants. Nevertheless, it is necessary to advance in the proposal of collaborative network projects, pushing the borders of scientific production. The increase in exchange between the graduate and research programs produces a mutually beneficial synergy that will certainly foster new advances.

It is worth highlighting the expressive contribution given by USP's School of Nursing Journal, which will be 50 years old in 2016. The journal is a valuable resource to publishing scientific production in nursing, thus helping disseminate the knowledge produced in this area.

Our continuing education program is undergoing a period of great demands, resulting from the establishment of eight residencies whose impact can be already felt. The resulting potential of EEUSP residents' presence still needs to be more widely explored and their interaction with undergraduate teaching is a goal to be pursued.

The institutional goals set by EEUSP express the concrete possibilities that this academic group identifies in face of the changes in the local university scenario, but also in a broader national scenario, where Brazil's National Education Plan ${ }^{(3)}$, research priorities, CAPES' guidelines for graduate program assessment, promotion agencies' sponsoring programs, and other structural and circumstantial conditions that deeply impact university life must be considered.

The EEUSP community, whose institutional engagement is significant, is being called to create alternative actions and keep moving forward. Only the active, committed participation by professors, technical and administrative staff, and undergraduate and graduate students can envisage the future to be built for this School and the University of São Paulo.

\section{REFERENCES}

1. Goldemberg J, coordenador. USP 80 anos [Internet]. São Paulo: Edusp; 2015 [citado 2016 jan. 23]. Disponível em: http://www.edusp.com.br/detlivro.asp?ID=1936545551

2. Universidade de São Paulo, Escola de Enfermagem. Projeto Político-Pedagógico do Curso de Graduação em Enfermagem da EEUSP [Internet]. São Paulo; 2016 [citado 2016 jan. 23]. Disponível em: http://www. ee.usp.br/site/index.php/paginas/mostrar/119/51

3. Brasil. Ministério da Educação. Plano Nacional de Educação (2014/2024) em movimento [Internet]. Brasília; 2016 [citado 2016 jan. 23]. Disponível em: http://pne.mec.gov.br 